\title{
Hierarchical Mapping of an Electric Vehicle Sensor and Control Network
}

\author{
István Nagy \\ Óbuda University, Bánki Donát Faculty of Mechanical \& Safety Engineering, \\ Institute of Mechatronics \& Vehicle Engineering, Dept. of Mechatronics \\ H-1081 Budapest, Népszínház u. 8, Hungary \\ Email: nagy.istvan@bgk.uni-obuda.hu
}

\begin{abstract}
This article reviews the electronic networks used in automotive engineering, with particular reference to a fully electric vehicle (EV). The block diagram of the electronic network of the vehicle is assembled on the basis of measurements and studies carried out on a university EV. The block diagram includes the network connections of sensors, actuators, switches, indicators, control systems, and sub-systems of the vehicle. After mapping the electrical network, the paper is briefly surveying the communication systems and control processors used in EV, then investigates the causes of the probabilities of the failures from the sensor core up to the control units. Regarding sensors investigation, the most important sensor, the wheel speed sensor, will be examined, then the LIN and CAN bus systems operation and its possible faults will be reviewed, analysed. At the end of the article, in the appendix, the complete electronic network of the vehicle can be seen.
\end{abstract}

Keywords: Control Units (CUs); Control Modules (CMs); Electric Vehicle Control (EVC); Vehicle Control Module (VCM)

\section{Introduction}

Nowadays electric vehicles are becoming more and more important in our lives. However, as manufacturers hold patents and guard their knowledge carefully, only a limited amount of information is passed on to researchers independent of any one manufacturer. This article tries to fill in some of the gaps in engineering research. Articles related to electric vehicles can be classified into the following categories.

- Articles dealing with charging options for electric devices, [1], [2]

- Articles dealing with controls, like the SRM motor's control and simulation [3] 
- Articles dealing with the kinematic and dynamic control of the unmanned vehicles [4]

- Articles examining the workings of the internal combustion engine and the electric motor in a hybrid EV (HEV). [5]

- Articles addressing the harness [6]

- Articles examining sensors used in EVs to monitor driver behaviour [7]

Although AMR sensors have been available to the industry for a relatively short period of time, there are nevertheless several studies looking at their theoretical basis [8], [9]. In this article, the AMR sensors used in vehicle engineering will be shown as the lower level of the control hierarchy.

Among the scientific articles or conference papers reviewed, the author did not find one which attempted to map the electronic, sensory, and control network of an EV. Therefore, this article will pay particular attention to this topic, by trying to map all the electric connections of a vehicle, and then by specifying the electrical path from sensor to $\mathrm{CU}$, and examining the communication systems.

The structure of the article can be summarized as follows.

After the introduction, the article reveals the electronic network of a particular $\mathrm{EV}$, and then deals with different communication (Bus) systems and protocols, used in vehicle engineering, where the different possible failures will be examined. In addition, the paper will highlight the path of the electric signal (impulse) from the wheel speed sensor to the onboard computer. In Section 4, the control units of the embedded systems will be surveyed, and some hierarchy will be built from the sensor core to the onboard processor. The article will conclude by summarizing the findings. There is also an appendix, in which the complete sensory and control network is mapped.

\section{Mapping the Electronic Control System of a Particular EV ${ }^{1}$}

It is not an easy task to begin to discover the electronic system of a vehicle without having the correct documentation. Thanks to the Institute for Computer Science and Control of the Hungarian Academy of Sciences (MTA SZTAKI) ${ }^{2}$, the author was able to obtain the service book [10] for the vehicle in question, from which a lot of useful information was derived.

\footnotetext{
${ }^{1}$ The particular EV is a NISSAN LEAF Z0, owned by Óbuda University.

${ }^{2}$ Hungarian Academy of Sciences, Institute for Computer Science and Control.
} 
The first step in mapping the electric network of a vehicle involves finding the main nodes of the network. Primarily the control modules, such as the Vehicle Control Module (VCM), and the Body Control Module (BCM) etc. were considered as main nodes, but the network seemed so chaotic that it needed to be divided into sub-systems. There are 9 sub-systems in this division (or 10, if EVB will be separated from EVC). The sub-systems contain one or more control modules that in some cases are almost directly (through some interfaces, which are usually integrated into the sensors) connected to the sensors, actuators, switches, indicators. Continuing this idea, in order of importance, the following sub-systems can be set up.

\subsection{EV Control System (EVC)}

This system should be classified as the main system of the vehicle. It contains two modules, the Vehicle Control Module (VCM), and the Intelligent Power Distribution Module in the Engine Room (IPDM E/R), see the darkened section in Fig. 1 (below). The EVC is responsible for the proper electric power train, and power transmission in the vehicle. Through the IPDM module, the "costeffective" (energy efficient) operation of the vehicle is controlled. A sub-system of this EVC is the EVB (EV Battery System), which controls the Li-ion battery system of the vehicle. Here the Power Delivery Module (PDM) plays the main role in the control. The PDM is connected to the Li-ion battery controller unit, which (among other things) monitors the battery current and battery temperature. The EV control system connections can be seen in Fig. 1.

The ASCD (Automatic Speed Control Device) cannot be neglected in this diagram. It allows a driver to keep the vehicle at a predetermined constant speed, without pressing the accelerator pedal (popularly this is known as a "tempo-mat" switch). The operation is the following: The VCM module receives the vehicle speed signal from the electronically-driven intelligent brake unit (ABS), processes it with the motor speed signal, and controls the traction motor to regulate vehicle speed. This is also known as cruise control. 


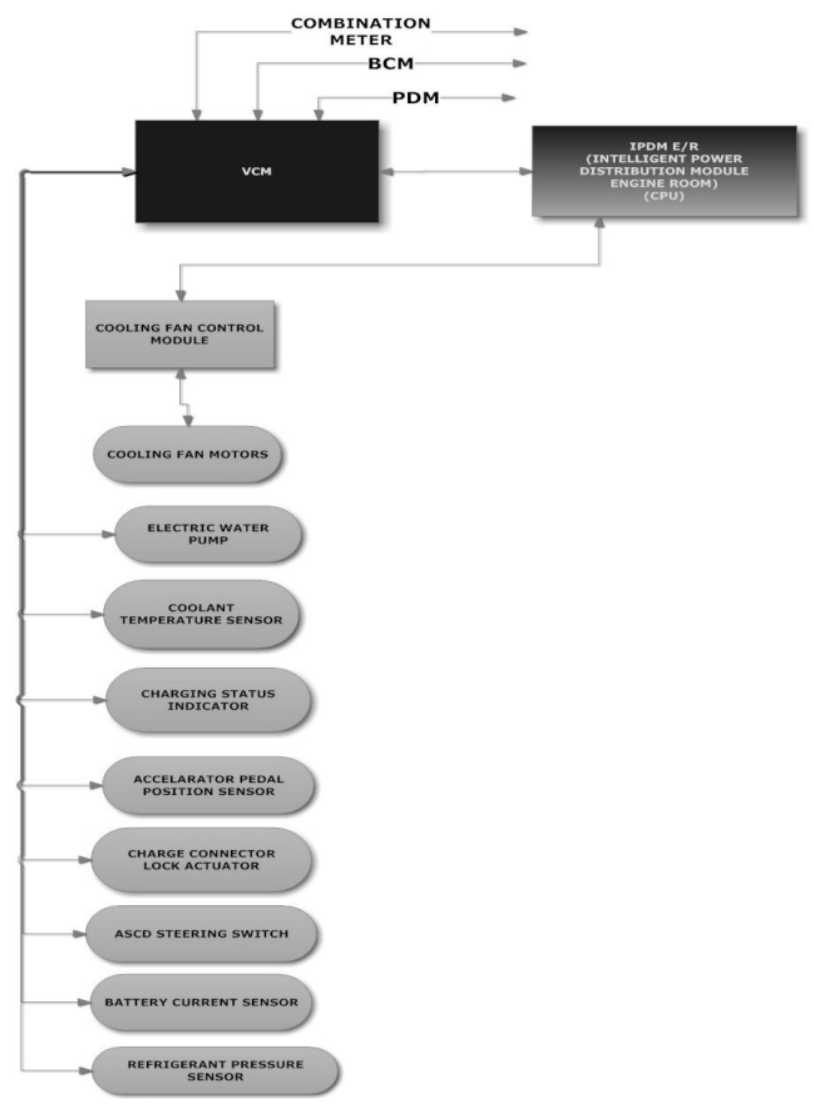

Figure 1

The EV sub-system

\subsection{Driver Control System}

This sub-system contains the most modules, units, sensors and actuators. Furthermore, it includes those parts of the system, which can be controlled or operated by the driver.

The diagram shows that the system contains three control MODULES (see darkened rectangles at the top, which are representing the top hierarchy level). Beneath are two control UNITS for "approaching vehicle sound for pedestrians" (APVSP) and "auto levelizer", two "combination switches" plus a "horn relay" (see, lighter rectangles, which are representing the middle level of hierarchy). Below these boxes, the SENSORS and ACTUATORS, as low level of hierarchy, can be found (see, elliptical shapes). The directed lines on the upper part of the diagram indicate the connections to other modules. Control units in the middle level of hierarchy are pre-processing the signals for the modules in the upper 
hierarchy level. Basically, the hierarchy from top to down is built up from MODULES; UNITS; ACTUATORS and SENSORS.

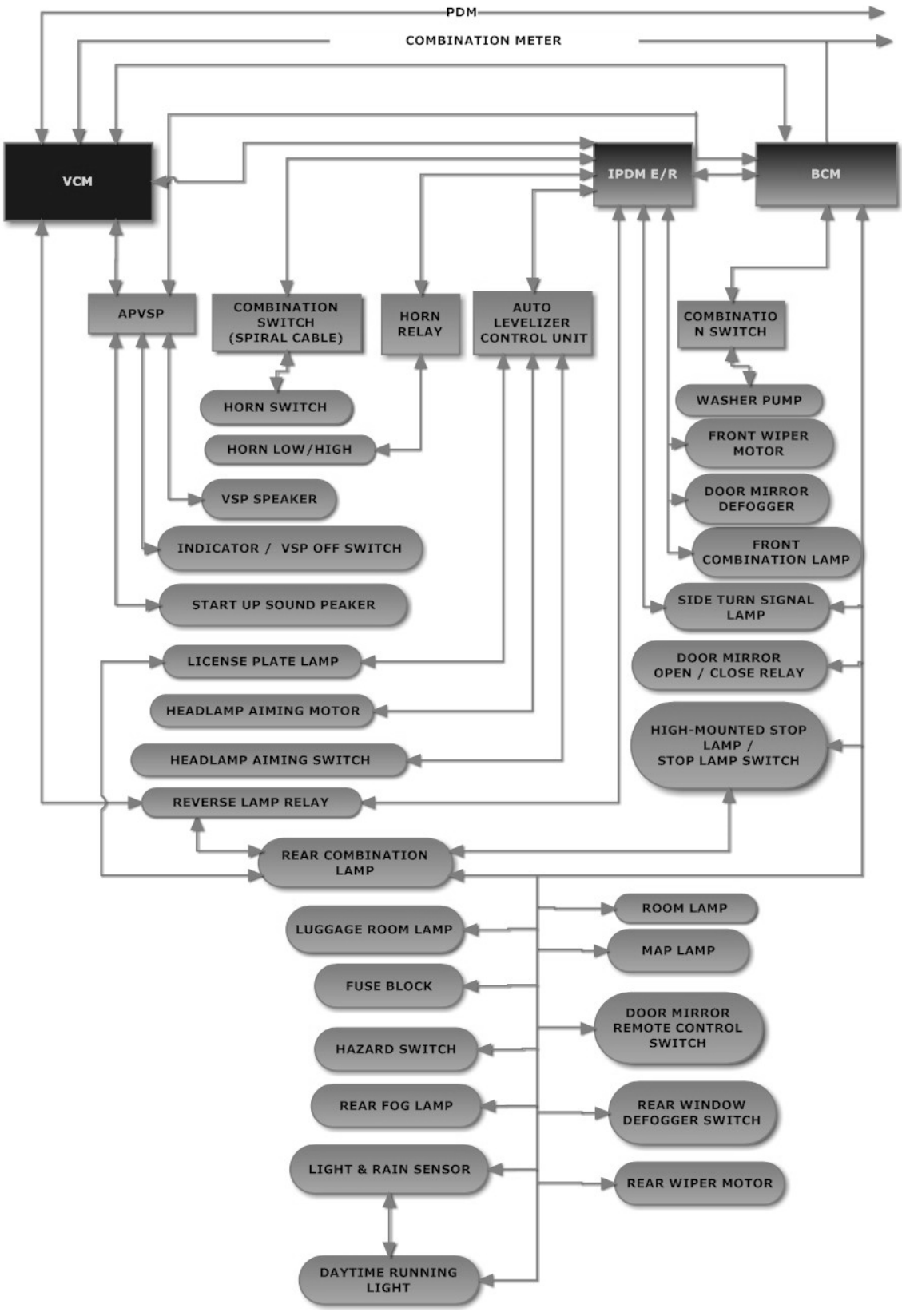

Figure 2

The electronic network of the Driver Control System 


\subsection{The Brake Control System and Electronically Controlled Power Steering System}

The importance of these sub-systems is in the driving dynamics properties of the vehicle. Here, the sensors and actuators are connected to the different control units in the medium hierarchy level, such as the electronically-driven Intelligent Brake Unit, the ABS actuator and the Electric Control Unit (ECU), EPS control unit. Further control units are connected to the modules, see the upper part of Fig. 3 (the arrows to the left).

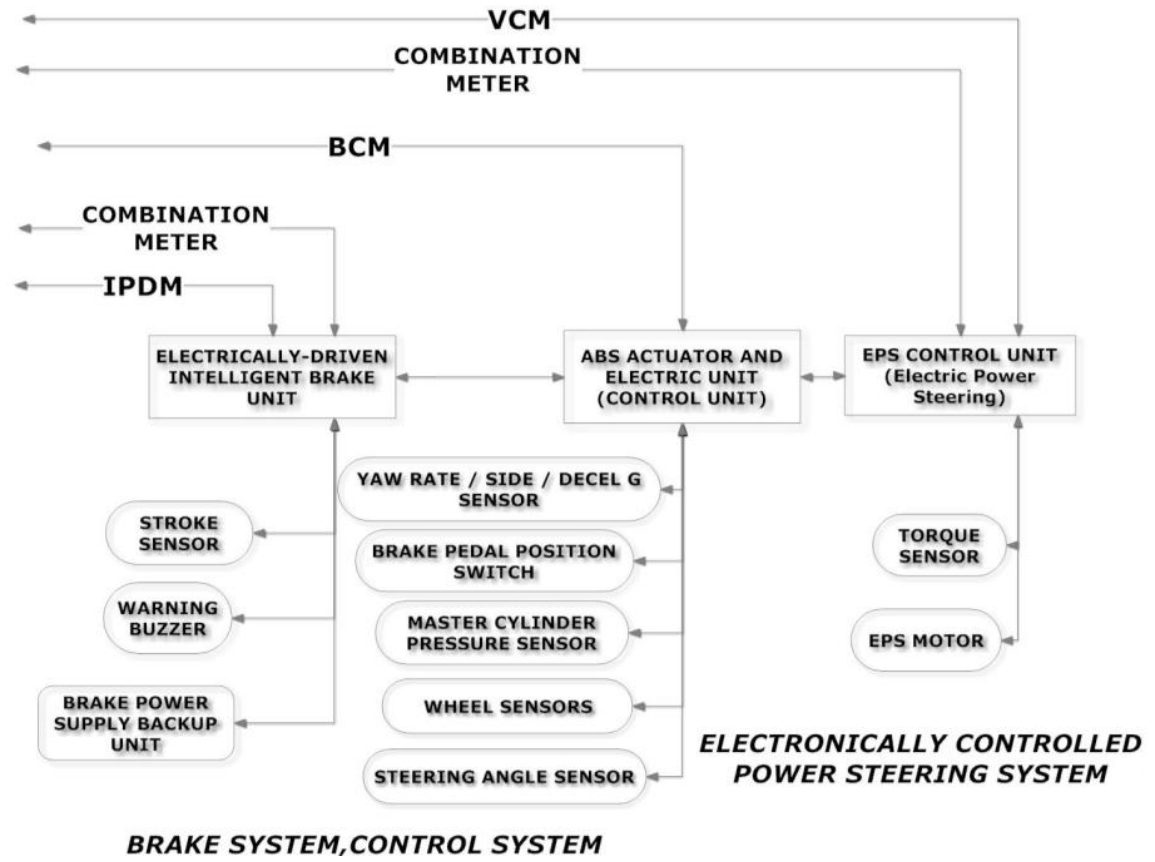

Figure 3

The Brake Control System (left) and the Electronically Controlled Power Steering System, EPS (right)

The task of units: electrically-driven intelligent brake unit integrates the control, master cylinder, brake booster, and checking the fluid pressure. This "reports" to the ABS actuator and electric unit, which is direct connected to the EPS Control Unit. Essentially this electrically-driven intelligent brake is a booster system that generates force to assist braking by using an internal motor to operate a piston inside the brake cylinder. The parking brake system (PBS) is also included in this system.

The EPS control unit performs an arithmetical operation on data, such as steering wheel turning force (sensor signal) from the torque sensor, vehicle speed signal, and EPS motor position signal, which is obtained from the EPS motor. 
It processes these signals and generates an optimum torque assist signal to the EPS motor appropriate for the driving conditions. In case of malfunction, the system enters into the manual steering mode.

\subsection{The Vehicle Charging System, Traction Motor System, and Electric Shift}

These three sub-systems are served by three modules (PDM, IPDM, VCM). Their operation will be discussed separately in the sub-sections below.

\subsubsection{Vehicle Charging System, Traction Motor System (Power Train)}

The task of the charging system is to make the most of the public power network (220/50) to charge the Li-ion batteries of the EV. The PDM plays a key role in this process. The charger uses two-converter systems, consisting of the Power Factor Correction (PFC) circuit and the DC/DC converter, which improve charging efficiency, charge level accuracy, and consequently the service life of a Li-ion battery. The PFC is a device that efficiently converts AC power supply input to slightly pulsing, but more energized DC power. The operation of the charging system is the following: the PDM detects the input power supply (either $110 \mathrm{~V}$ or $220 \mathrm{~V}$ ) and switches the charger to the appropriate mode. Then the AC source is filtered and rectified by the 2-way rectifier. Then the PFC improves and boosts the power factor of the rectified signal. This boosted signal is again converted to AC by the inverter. The insulation transformer converting the AC to the high-voltage and the $2^{\text {nd }}$ rectifier results in high-voltage DC power. In addition to all of this, the insulation transformer separates the charging circuits from the vehicle's circuits. The whole process can be seen in Fig. 4.

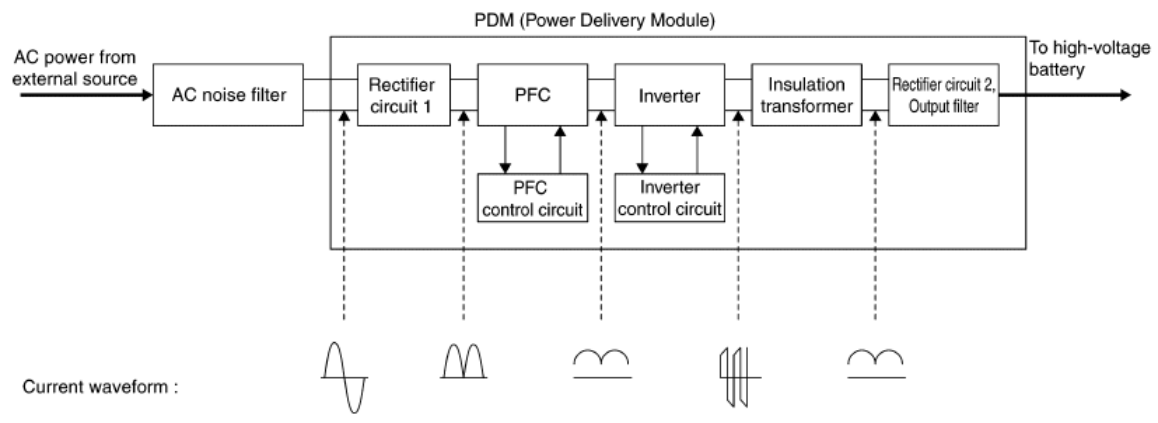

Figure 4

The EV charging process

The possibility of solar charging should also be mentioned here. This type of vehicle is equipped with a solar cell module to charge the $12 \mathrm{~V}$ battery. Charging depends on the power generation of the cells, which depends on the amount of 
solar radiation available. The battery is not recharged, when this amount of power is low. The ideal conditions can be described approximately as being fair weather, with the temperature around $25^{\circ} \mathrm{C}$, and between $11 \mathrm{am}$ and $2 \mathrm{pm}$, with the cell clean and in sunlight. Charging occurs when the emf (electro-motive force) of the cell is more than the battery voltage. The charging current corresponds to the potential difference between the battery and the emf of the cell.

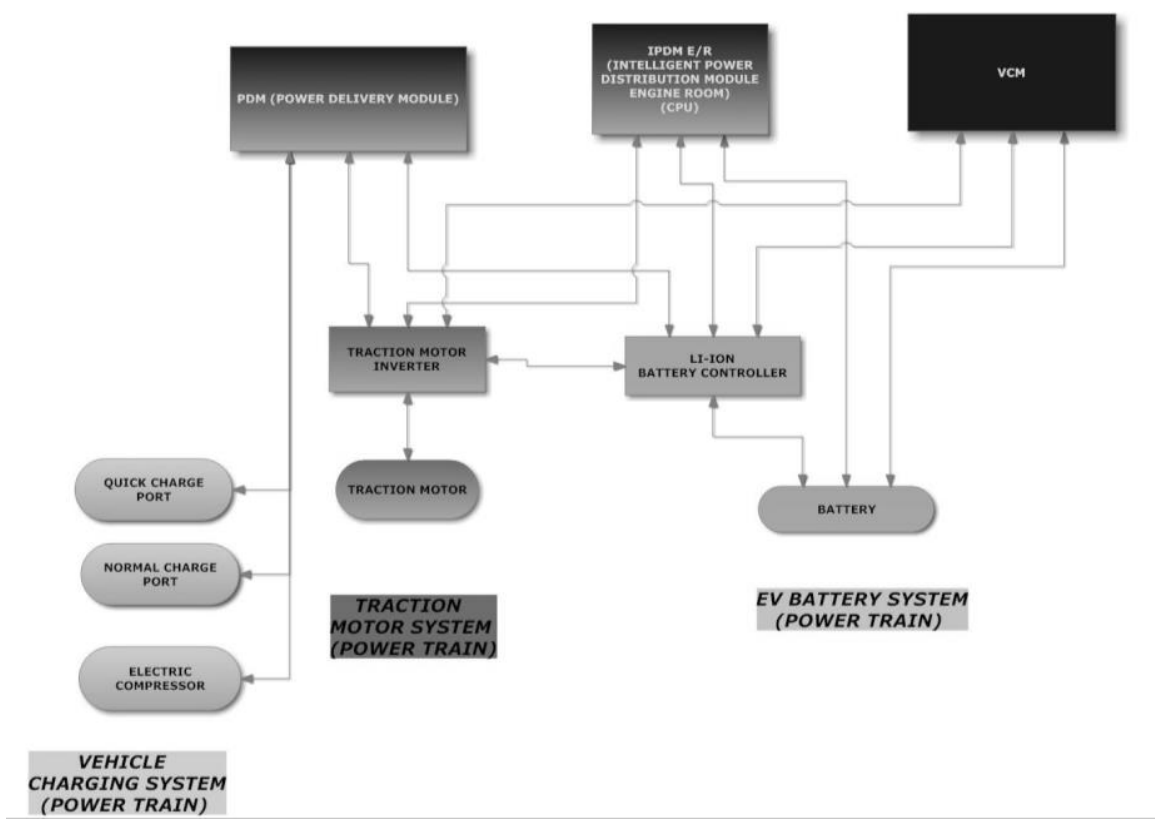

Figure 5

Vehicle charging System and the Power Train

\subsubsection{Traction Motor (power train) System and Electric Shift Control Module}

The traction motor is a compact Interior Permanent Magnet Synchronous Motor (IPMSM) with high power output and high efficiency. Essentially this is a 3-phase synchronous AC motor, with an electronic IGBT (Insulated Gate Bipolar Transistor) commutation. The traction motor inverter converts the DC power, from the Li-ion battery to the AC power, which drives the motor. The AC power frequency and voltage created can be varied with the DC converter, which results in a high control performance of the IPMSM. The traction motor inverter can be regarded as the motor controller, because it regulates the motor performance based on the required motor torque signal obtained from the EV System of the VCM. The regulation accuracy of torque is based on the current sensor detection signal, while the RPM (which is sensed by the traction motor resolver) depends on the 
frequency of the 3-phase current. Moreover, the traction motor inverter performs vibration control in order to improve accelerator response and provide better acceleration during driving.

The Electric Shift Control Module is built into the VCM, and determines the shift position, based on the shift position data captured from the electric shift sensor. It transmits data to the VCM and traction motor inverter via the CAN Bus system. This module also controls the parking actuator, based on the signal from the position of the Electric Shift Selector (known commonly as the gearstick).

The components of the Traction Motor System (power train) are the following: traction motor, connected to the traction motor inverter, which is controlled through the PDM (see Fig. 5).

\subsection{Tyre Pressure, SRS Air Bag and Body Exterior (door, window, security) Systems}

Because this article trying to map the connections between the sensors and their controllers, so the author will focus on these devices in these sub-systems.

\subsubsection{Body Exterior and Security System}

With the emphasis on safety equipment, first the sensors/actuators will be described, which can be found in this sub-system. The intelligent-key antennas (outside-rear, outside-passenger side, outside-driver side; inside-luggage room, inside-rear seat, inside-instrument centre) can detect when the legitimate owner is near the vehicle, and based on this, when the key lock is touched, unlock the steering wheel. The communication between the key and the units goes through the NATS (Nissan Anti-Theft System) antenna. The units transmit the signal towards the BCM module. One of the units is the Siren Control Unit, which monitors the vehicle condition and controls the vehicle security system. The intruder sensor detects movement in the passenger compartment and then transmits a signal to the siren control, which transmits it onto the BCM. The power door lock system is also part of the intelligent key system. Given all this, the BCM can be regarded as the key module for car security. 


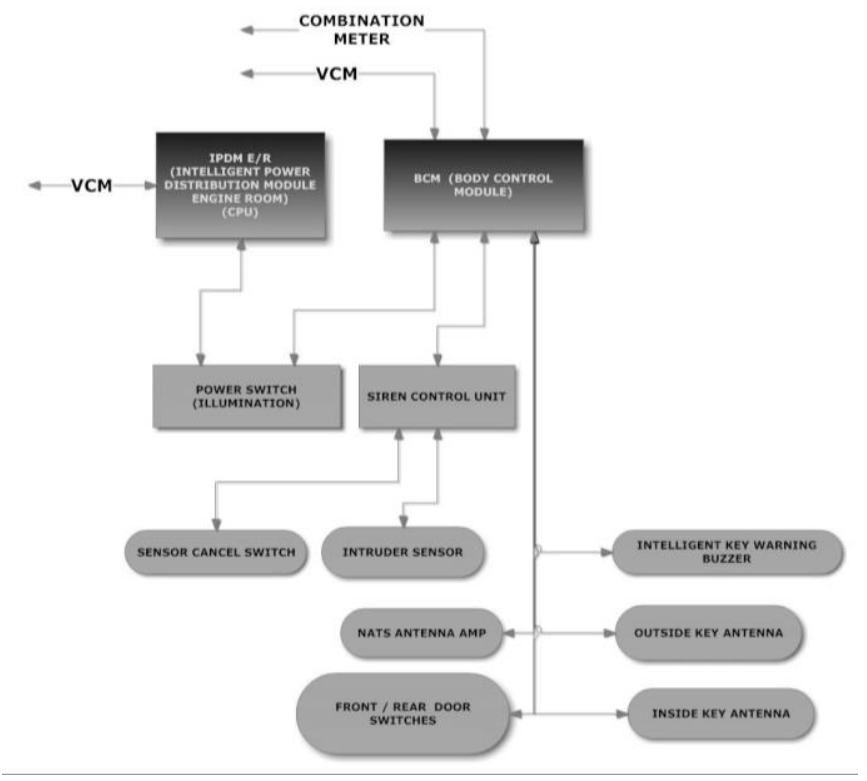

Figure 6

The Body Exterior and Security System

\subsubsection{Tyre Pressure and SRS Air Bag Systems}

The Supplemental Restraint System (SRS), regarding the sensors, can be divided into two main modules: air bag diagnosis sensor - controlling the airbags, and the crash zone sensor - integrating the crash sensors' data. The main parts of the system are as follows: the spiral cable, which provides the connection between the airbag diagnosis sensor and the driver airbag module; the crash zone sensorintegrating the frontal collision sensor and the satellite sensor (for lateral and rollover collisions); the airbag diagnosis sensor - controlling the driver airbag, passenger airbag, side airbag, curtain airbag, seatbelt pre-tensioner, lap pretensioner. 


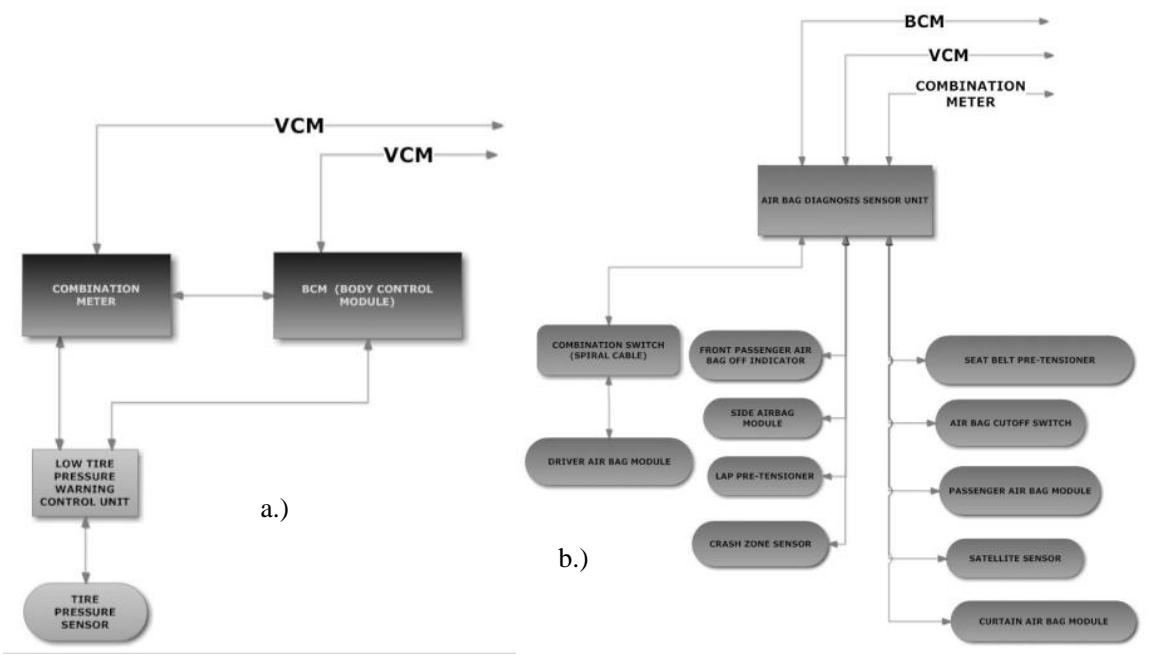

Figure 7

The Tyre Pressure a) and SRS Air Bag System b)

Regarding tyre pressure, basically, two types of sensors can be distinguished. The direct sensors are mounted directly onto each wheel and measure the air pressure inside each individual tyre, while the indirect sensors work with the ABS, evaluating the tyre pressures from the wheel speeds (if the tyre pressure is low, the wheel is rolling with different speed, because the nominal diameter of the wheel is decreased). The indication of low pressure is displayed on a combination meter, see Fig. 7 a).

\subsection{Summary of Electronic Control System Mapping}

In the summary, the individual sub-systems and the real control modules (boxed units), connections will be illustrated, (see below). In some previously published conference papers [11], published by the author, several stand-alone sub-systems were examined. Portrayal of the whole system, with this level of complexity, is published for the first time here. 


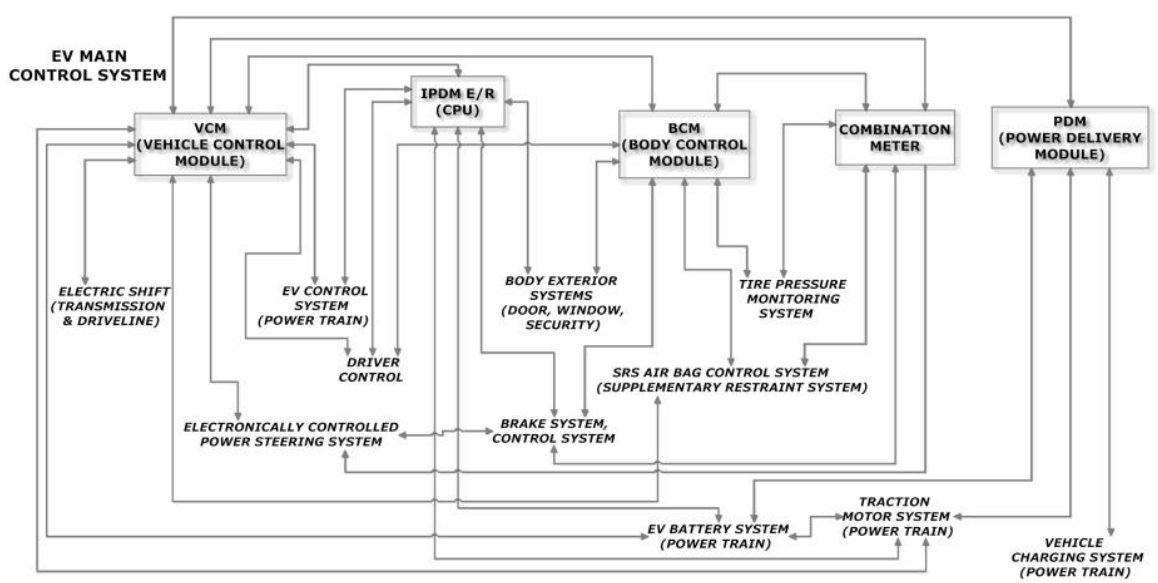

Figure 8

The Control Modules and the Sub-system's relations

\section{Communication Systems used in EVs}

In this section the most frequently used communication systems of vehicles will be surveyed. The author has already partly addressed this issue in a previously published paper [12], where the CAN system was examined, so this will be only referred to in this section. The communication systems, given the medium of communication, can be enrolled into two main classes, namely wired and wireless communications. Systems can be classified further based on the distance between the communication devices: in-vehicle communication $(\operatorname{InV})$, and communication outside the vehicle. Outside communication can be classified still further into medium (car to car $(V 2 V)$, or car to infrastructure $(V 2 I)$ ) and long (car-satellite $(V 2 S)$ or car to everything $(V 2 X))$ range communications. Table 1 summarizes the communication systems.

Table 1

Vehicle Communications Systems

\begin{tabular}{|c|c|c|c|}
\hline \multicolumn{2}{|c|}{ In-Car System } & \multicolumn{2}{c|}{ Outside of Car } \\
\hline $\begin{array}{c}\text { Wired } \\
(\operatorname{In} V)\end{array}$ & $\begin{array}{c}\text { wireless } \\
(\operatorname{In} V)\end{array}$ & $\begin{array}{c}\text { medium(short }) \\
\text { range }(V 2 V, V 2 I)\end{array}$ & $\begin{array}{c}\text { long range } \\
(V 2 I, V 2 X, V 2 S)\end{array}$ \\
\hline LIN & BlueTooth & mmWave $(\sim 50 \mathrm{~m})$ & Cellular Techs $(\sim 15 \mathrm{~km})$ \\
\hline CAN & UWB & $5 \mathrm{G}(\sim 50 \mathrm{~m})$ & WiMax $(\sim 40 \mathrm{~km})$ \\
\hline FlexRay & ZigBee & WiFi $(50 \mathrm{~m}-1 \mathrm{~km})$ & LTE-A-Pro $(\sim 30 \mathrm{~km})$ \\
\hline MOST & & DSCR $(\sim 1 \mathrm{~km})$ & UMTS $(\sim 10 \mathrm{~km})$ \\
\hline $\begin{array}{c}\text { Automotive } \\
\text { Ethernet }\end{array}$ & & & GPS $(V 2 S)$ \\
\hline
\end{tabular}


The diagrams, prepared above (see Section 2), use communication systems highlighted in grey in the table. In the next two sections, these will be detailed.

\subsection{The Local Interconnect Network (LIN)}

In the hierarchy of the automotive communicative network, the LIN is located on the lowest level. It usually connects the switches or indicators (lamps) to the control units, located under the control modules, in the lowest level of the electrical network. The "one master-multi slave", the bus-topology network is driven by UART/SCI interface and realized by one wire with a maximum length of $40 \mathrm{~m}$, and with a maximum number of 16 slave nodes. It has a selfsynchronizing ability (in frame header is the synchronizing field) and good flexibility.

\subsubsection{Possible Malfunctions}

Table 2

The malfunctions and symptoms of LIN communication

\begin{tabular}{|l|l|}
\hline \multicolumn{1}{|c|}{ malfunction } & \multicolumn{1}{c|}{ symptom } \\
\hline $\begin{array}{l}\text { Power supply voltage is out of range (8- } \\
18)[\mathrm{V}]\end{array}$ & $\begin{array}{l}\text { The ECU of LIN still operates, but the } \\
\text { communication is not guaranteed }\end{array}$ \\
\hline Losing the power supply or GND & $\begin{array}{l}\text { The unpowered ECUs (slaves) do not } \\
\text { obstruct the normal communication }\end{array}$ \\
\hline Shortcut between power supply and GND & $\begin{array}{l}\text { The communication breaks down, but no } \\
\text { damage occurs. After removing the error, } \\
\text { the system will operate normally. }\end{array}$ \\
\hline
\end{tabular}

Regarding bit-rate and signal distortion, it is important to know the capacity $\left(C_{B U S}\right)$ and resistance value $\left(R_{B U S}\right)$ of the Bus, because the time constant $(\tau)$ determines the signal change rate at the rising edge (slope) of the signal. The calculation is based on the following equations [13].

$$
C_{B U S}=C_{\text {MASTER }}+n \cdot C_{S L A V E}+C_{\text {LINE }}^{\prime} \text {. Length }{ }_{B U S}
$$

and the BUS resistance

$$
R_{\text {BUS }}=R_{\text {MASTER }} \times R_{\text {SLAVE1 }} \times \ldots \times R_{\text {SLAVEn }}
$$

the time constant, which influences the signal shape, and bit rate

$$
\tau=C_{B U S} \cdot R_{B U S}
$$

where " $n$ " is the number of slave nodes, $C^{\prime}{ }_{\text {LINE }}$ is the BUS capacity on unit length. 


\subsubsection{LIN Applications in Vehicle Engineering}

The LIN's communication method has the following advantages: ease of use, relative simplicity, cheapness, wide availability of components, simple harness, and the flexibility of extension. What is known as non-demanding equipment (listed below) uses this communication.

Table 3

The practical applications of LIN communication

\begin{tabular}{|c|c|}
\hline segment of operation & practical use \\
\hline The roof & Light sensor, light control, sunroof \\
\hline Steering wheel & $\begin{array}{c}\text { Cruise Control Sw., wiper, turning light, } \\
\text { radio, wheel lock - switches }\end{array}$ \\
\hline Seats & Seat position motor and sensors \\
\hline Engine & Cooling fan motor \\
\hline Climate & Small motors, control panel \\
\hline Door & Mirrors, window lift, door lock \\
\hline
\end{tabular}

\subsection{Controller Area Network (CAN)}

The CAN Bus system of this particular vehicle and possible CAN Bus failures, regarding shorted and opened circuits, are discussed in [12], so the author will just make reference to it. Here, in this article the CAN connections of diagrams described earlier in Section 2 will be shown.

There are 5 main Control Modules (CMs) in the EV Control System (VCM, BCM, IPDM E/R, PDM, Combination meter) which are connected to each other via this $(\mathrm{CAN})$ protocol. Moreover, the connections between the Control Units (there are 9 control units (CUs): VSP, Auto levelizer CU, Li-ion Battery Controller, EPS, Tyre pressure $C U, A B S C U$, Electrically-driven intelligent brake $C U$, cooling Fan $C U$, SRS Airbag $C U$ ) and Control Modules are also realized through the CAN Bus system. Not only this but further down the network hierarchy, some intelligent sensors (like AMR wheel Speed sensors) are also connected via CAN to their control units. After mapping the electronic system of the vehicle a table of signals and control units communicating on the CAN Bus system can be created. (Due to the limitations of the size of the paper, the full table will not be displayed).

The table can be useful in searching for possible communications failures in the Bus system. For example, the vehicle is in motion, but the speedometer (tachometer, part of combination meter) is not moving. The table shows that a signal should be transmitted (T) by the ECM and received (R) by the Combination meter. Therefore, one can conclude that in this case, the transmission of a signal between the ECM and the Combination meter is not functioning properly. 
Table 4

The signals that travel on CAN System and main CMs

\begin{tabular}{|c|c|c|c|c|c|c|}
\hline $\begin{array}{l}\text { Control Units } \\
\text { Signal name }\end{array}$ & ECM & BCM & $\begin{array}{l}\text { Combination } \\
\text { meter }\end{array}$ & STRG $^{3}$ & ABS & $\begin{array}{l}\text { IPDM } \\
\text { E/R }\end{array}$ \\
\hline $\begin{array}{l}\text { A/C compressor } \\
\text { feedback }\end{array}$ & $\mathrm{T}$ & & $\mathrm{R}$ & & & \\
\hline $\begin{array}{l}\text { A/C compressor } \\
\text { request }\end{array}$ & $\mathrm{T}$ & & & & & $\mathrm{R}$ \\
\hline $\begin{array}{l}\text { Accelerator pedal } \\
\text { position }\end{array}$ & $\mathrm{T}$ & & & & $\mathrm{R}$ & \\
\hline $\begin{array}{l}\text { Cooling fan } \\
\text { motor operation }\end{array}$ & $\mathrm{T}$ & & & & & $\mathrm{R}$ \\
\hline $\begin{array}{l}\text { Engine coolant } \\
\text { temperature }\end{array}$ & $\mathrm{T}$ & & $\mathrm{R}$ & & & \\
\hline $\begin{array}{l}\text { Engine speed } \\
\text { signal }\end{array}$ & $\mathrm{T}$ & & $\mathrm{R}$ & & $\mathrm{R}$ & \\
\hline $\begin{array}{l}\text { Fuel consumption } \\
\text { monitor signal }\end{array}$ & $\mathrm{T}$ & & $\mathrm{R}$ & & & \\
\hline $\begin{array}{l}\text { Malfunction } \\
\text { indicator lamp } \\
\text { signal }\end{array}$ & $\mathrm{T}$ & & $\mathrm{R}$ & & & \\
\hline$A / C$ switch signal & $\mathrm{R}$ & $\mathrm{T}$ & & & & \\
\hline $\begin{array}{l}\text { Ignition switch } \\
\text { signal }\end{array}$ & & $\mathrm{T}$ & & & & $R$ \\
\hline $\begin{array}{l}\text { Sleep / wake up } \\
\text { signal }\end{array}$ & & $\mathrm{T}$ & $\mathrm{R}$ & & & $\mathrm{R}$ \\
\hline$\ldots$ & & & & & & \\
\hline
\end{tabular}

\section{Control Circuits Used in EVs}

After mapping the electronic circuits of the vehicle a hierarchical system begins to emerge. At the bottom of this system are lamps, indicators, sensing core of the sensors, and on the top is the VCM. Based on this hierarchy, different control circuits are used for signal transferring and data processing. In the case of vehicle engineering, the control units are embedded systems. The embedded systems usually consist of (in order: Input $\rightarrow$ Output): sensors, signal conditioning unit, central control unit, output interface, actuator, or indicator. The control circuits, including processors, can be either a microcontroller, microprocessor, or highcomplexity control logic, e.g. CPLD / FPGA.

\footnotetext{
${ }^{3}$ Steering Unit
} 
The central control units can be classified into three main classes, where the top class is the General Purpose Processor (GPP). Main features: relative low speed but high complexity, supporting on-chip DMA, and on-chip Cache, provides HW circuits for commonly used math and logic operations, uses pipeline, and wide data buses, and at the end, the cost is relatively high. Summary: high complexity and flexibility, relatively high cost, relatively low performance.

The Application Specific Instruction set Processor (ASIP) can be put into the medium class of control circuits. This uses SoC (System on Chip) technology and the set of instructions is usually tailored to the task. The medium class is between the flexibility of GPP and the performance of ASIC circuits. Summary: performance many times faster than GPP, effective with a smaller number of instructions, less complexity, medium flexibility.

The lower class of control circuits form the Application Specific Integrated Circuits (ASIC). The word "lower" is not used pejoratively but simply means that this type of controller is near to the physical level control. The circuits have low flexibility and complexity, but very high performance for the given task. It has no instruction set, but instead, the program is burned into the IC. They are available in two versions: semi-customized, where the circuit contains pre-programmed segments; fully customized, where the circuit is fully designed by the developer. Most known among such circuits are the PAL, PLA, GAL circuits, and somewhere a little bit higher the FPGAs and CPLDs. Summary: high performance, fitted to the given task, relatively low cost, and very low flexibility.

At the end of section, the control circuits that can be assigned to different levels of the hierarchy are summarized, see Fig. 9.

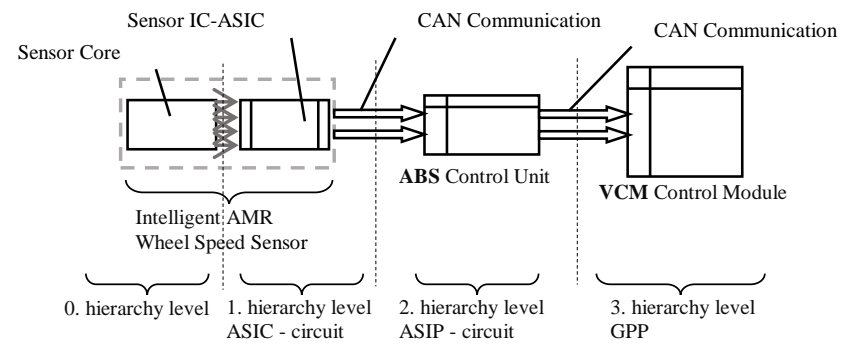

Figure 9

The hierarchy levels from sensor core to the top level of hierarchy and the possible control circuits in different levels

\section{Conclusions}

In this paper, the electronic control network of a particular vehicle has been introduced. References [11] and [12], where the communication and the AMR wheel speed sensors are detailed, make this article more complete. 
The author has tried to explore the connections between the sensors, indicators, switches, and the control unit in a specific EV, by dividing the whole system into operational sub-systems, mapping these sub-systems in detail. (Section 2) The sub-systems and their connectivity to the control modules are illustrated on Fig. 8. Finally, the whole map of the connectivity is presented in Attachment nr. 1. The mapped system can provide a very good base for further analysis of errorspreading on the network (something the author plans to examine in a future paper), or for evaluation of the reliability of the system [14], and not less in graphmodel creating of the system [15].

Table 5

NOMENCLATURE

\begin{tabular}{|c|c|c|c|c|c|c|c|}
\hline $\begin{array}{c}\text { Acro- } \\
\text { nym }\end{array}$ & Meaning & $\begin{array}{c}\text { Acro- } \\
\text { nym }\end{array}$ & Meaning & $\begin{array}{c}\text { Acro- } \\
\text { nym }\end{array}$ & Meaning & $\begin{array}{c}\text { Acro- } \\
\text { nym }\end{array}$ & Meaning \\
\hline ABS & $\begin{array}{l}\text { Anti-lock } \\
\text { Braking System }\end{array}$ & CU & Control Unit & HEV & $\begin{array}{ll}\text { Hybrid } & \text { Electric } \\
\text { Vehicle } & \\
\end{array}$ & PFC & $\begin{array}{l}\text { Power Factor } \\
\text { Correction }\end{array}$ \\
\hline AMR & $\begin{array}{l}\text { Anisotropic } \\
\text { Magneto- } \\
\text { Resistive } \\
\text { (sensor) }\end{array}$ & DMA & $\begin{array}{l}\text { Direct Memory } \\
\text { Acces }\end{array}$ & IGBT & $\begin{array}{l}\text { Insulated Gate } \\
\text { Bi-polar } \\
\text { Transistor }\end{array}$ & PLA & $\begin{array}{l}\text { Programmable } \\
\text { Logic Array }\end{array}$ \\
\hline APVSP & $\begin{array}{l}\text { Approaching } \\
\text { Vehicle Sound } \\
\text { for Pedestrians }\end{array}$ & EMF & $\begin{array}{l}\text { Electro-motive } \\
\text { Force }\end{array}$ & IPDM & $\begin{array}{l}\text { Intelligent Power } \\
\text { Distribution } \\
\text { Module }\end{array}$ & $\mathbf{R}$ & Receiver \\
\hline ASCD & $\begin{array}{l}\text { Automatic } \\
\text { Speed Control } \\
\text { Device }\end{array}$ & EPS & $\begin{array}{l}\text { Electric Power } \\
\text { Steering System }\end{array}$ & $\begin{array}{l}\text { IPDM } \\
\text { E/R }\end{array}$ & $\begin{array}{l}\text { Intelligent Power } \\
\text { Distribution } \\
\text { Module, } \\
\text { Engine Room }\end{array}$ & RPM & $\begin{array}{l}\text { Rotation per } \\
\text { Minute }\end{array}$ \\
\hline ASIC & $\begin{array}{l}\text { Application } \\
\text { Specific } \\
\text { Integrated } \\
\text { Circuit }\end{array}$ & EV & Electric Vehicle & IPMSM & $\begin{array}{l}\text { Interior } \\
\text { Permanent } \\
\text { Magnet } \\
\text { Synchronous } \\
\text { Motor }\end{array}$ & SoC & $\begin{array}{l}\text { System on } \\
\text { Chip }\end{array}$ \\
\hline ASIP & $\begin{array}{l}\text { Application } \\
\text { Specific } \\
\text { Instruction-set } \\
\text { Processor }\end{array}$ & EVB & $\begin{array}{l}\text { Electric Vehicle } \\
\text { Battery System }\end{array}$ & LIN & $\begin{array}{l}\text { Local } \\
\text { Interconnect } \\
\text { Network }\end{array}$ & SRS & $\begin{array}{l}\text { Supplemental } \\
\text { Restraint } \\
\text { System }\end{array}$ \\
\hline BCM & $\begin{array}{l}\text { Body control } \\
\text { Module }\end{array}$ & EVC & $\begin{array}{l}\text { Electric Vehicle } \\
\text { Control System }\end{array}$ & NATS & $\begin{array}{l}\text { Nissan Anti- } \\
\text { Theft System }\end{array}$ & $\mathbf{T}$ & Transmitter \\
\hline CAN & $\begin{array}{l}\text { Controller Area } \\
\text { Network }\end{array}$ & FPGA & $\begin{array}{l}\text { Field } \\
\text { Programmable } \\
\text { Gate Array }\end{array}$ & PAL & $\begin{array}{l}\text { Programmable } \\
\text { Array Logic }\end{array}$ & VCM & $\begin{array}{l}\text { Vehicle } \\
\text { Control } \\
\text { module }\end{array}$ \\
\hline $\mathbf{C M}$ & Contol Module & GAL & $\begin{array}{l}\text { General Array } \\
\text { Logic }\end{array}$ & PBS & $\begin{array}{l}\text { parking brake } \\
\text { system }\end{array}$ & & \\
\hline CPLD & $\begin{array}{l}\text { Complex } \\
\text { Programmable } \\
\text { Logic Device }\end{array}$ & GPP & $\begin{array}{l}\text { General Purpose } \\
\text { Processor }\end{array}$ & PDM & $\begin{array}{l}\text { Power } \\
\text { Distribution } \\
\text { Module } \\
\end{array}$ & & \\
\hline
\end{tabular}

\section{Acknowledgement}

The research presented in this paper was carried out as part of the EFOP 3.6.2-162017-00016 project in the framework of the Széchenyi Plan. The completion of this project is funded by the European Union and co-financed by the European Social Fund. 


\section{References}

[1] N. D. Mazharov, S. M. Hristov, D. A. Dichev, I. S. Zhelezarov: Some Problems of Dynamic Contactless Charging of Electric Vehicles; Acta Polytechnica Hungarica, Vol. 14, Nr. 4, 2017, pp. 7-26

[2] P. Kádár, A. Varga: Photo Voltaic EV charge Station; in $11^{\text {th }}$ International Symposium on Applied Machine Intelligence and Informatics (SAMI 2013) IEEE, ISBN 978-1-4673-5929-0, Herlany, Slovakia, pp. 57-60

[3] S. Sadeghi, M. Mirsalim, A. H. Isfahani: Dynamic Modelling and Simulation of a Switched Reluctance Motor in a Series Hybrid Electric Vehicle; Acta Polytechnica Hungarica, Vol. 7, Nr. 1, 2010, pp. 51-71

[4] B. Lantos, Zs. Bodó: High Level Kinematic and Low Level Nonlinear Dynamic Control of Unmanned Ground Vehicles; Acta Polytechnica Hungarica, Vol. 16, Nr. 1, 2019, pp. 97-117

[5] Zs. Preitl, P. Bauer, J. Bokor: Cascade Control Solution for Traction Motor for Hybrid Electric Vehicles; Acta Polytechnica Hungarica, Vol. 4, Nr. 3, 2007, pp. 75-88

[6] T. Sawatdee, P. Chutima: Design Process Improvement for Electric Car Harness; MOIME2017, in IOP Conference Series: Materials Science and Engineering 215 (2017) 012011, DOI:10.1088/1757-899X215/1/012011, pp. 1-7

[7] G. Fördős, I. Bosznai, L. Kovács, B. Benyó, Z. Benyó: Sensor-net for Monitoring Vital Parameters of Vehicle Drivers; Acta Polytechnica Hungarica, Vol. 4, Nr. 4, 2007, pp. 25-36

[8] R. Guyol: "AMR Angle Sensors", in analog Devices, Inc. AN12487-010/14(0), 2014, p. 4

[9] R. Slatter: Magnetoresistive (MR) sensors for Angle-, Path- and Current Measurement in Harsh Environments; AMA Conferences 2015, Sensor 2015 and IRS 2015, DOI 10.5162/sensor2015/B3.1, pp. 228-233

[10] Nissan Leaf Z0, Service Book, Electrical \& Power Control, Section: Power Supply, Ground \& Circuit Elements, 2013

[11] I. Nagy, Sz. Tuloki: Fault Analysis and System Modelling in Vehicle Engineering; in Proc of IEEE $18^{\text {th }}$ International Symposium on Computational Intelligence and Informatics (CINTI 2018), Budapest, Hungary, 2018, pp. 313-319

[12] I. Nagy, F. B. Vér: Practical Analysis of an AMR Wheel Speed Sensor and CAN Bus System for the Communication's Failures and its Implications to the EV's Control System; in IEEE 17 ${ }^{\text {th }}$ International Symposium on Intelligent Systems and Informatics Proceedings (SISY 2019) Subotica, Serbia, pp. 241-247 
[13] D. Fodor, Zs. Szalay: Autóipari kommunikációs eszközök; Pannon Egyetem, 2014, pp. 46-116

[14] L. Pokorádi, P. Felker: Interval Uncertainty Analysis of Bridge Structure Systems' Reliability (SISY 2019) IEEE, $17^{\text {th }}$ International Symposium on Intelligent Systems and Informatics, September 12-14, 2019, Subotica, Serbia, pp. 235-239

[15] L. Pokorádi, "Graph model-based analysis of technical systems", IOP Conference Series: Materials Science and Engineering 393 : 1 Paper: 012007, 8 p. (2018) 


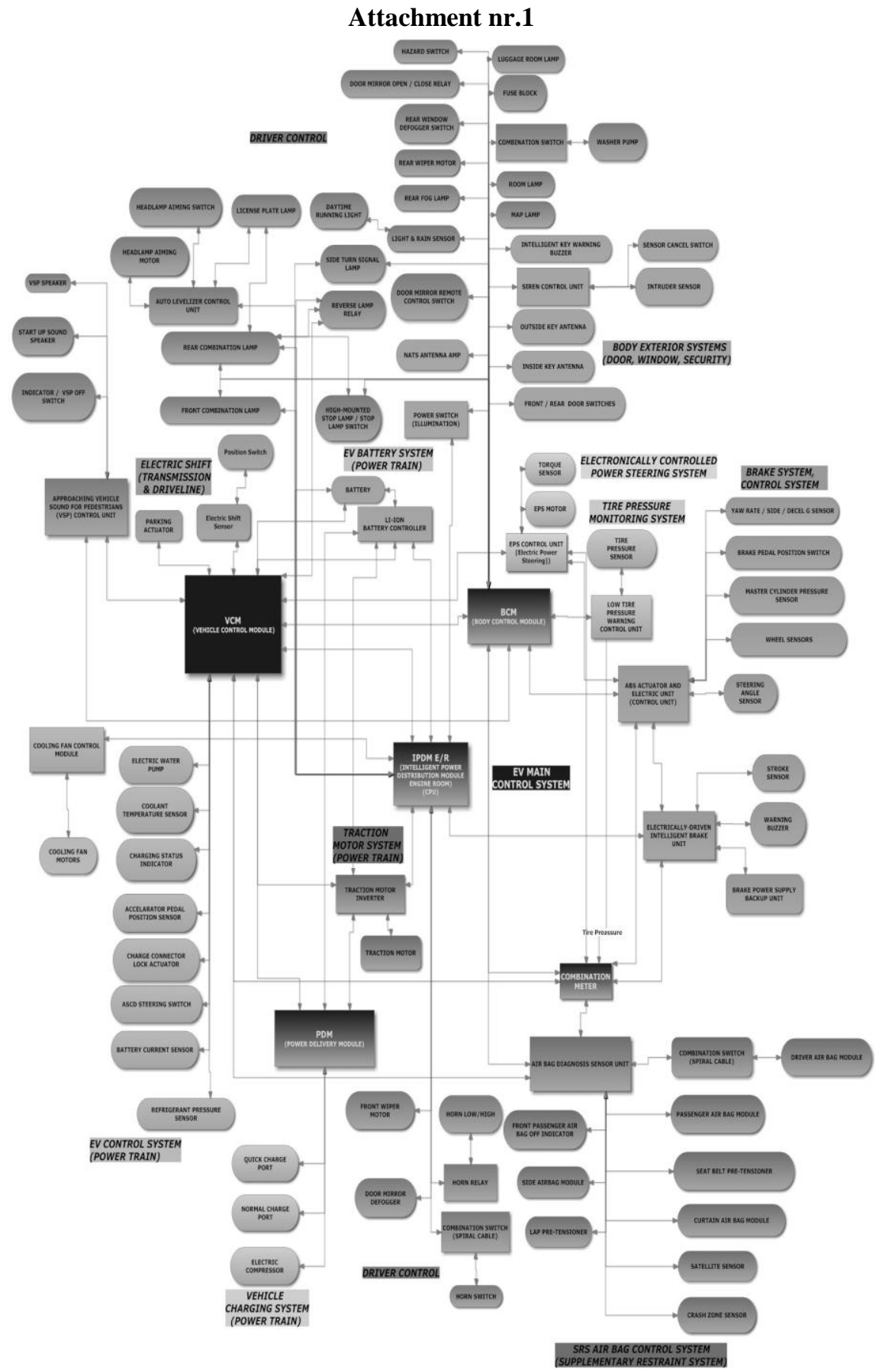

